\title{
The relationship between nephropathy, retinopathy, obesity and arterial stiffness in type 2 diabetes mellitus
}

\author{
Tip 2 diabetes mellitus tanılı hastalarda nefropati, retinopati, obezite ve \\ arteriyel sertlik arasındaki ilişki
}

\author{
Bilgin Demir, ${ }^{1}$ Sibel Demiral Sezer, ${ }^{1}$ Ömercan Topaloğlu, ${ }^{2}$ Emin Taşkıran, ${ }^{1}$ \\ Burcu Işık, ${ }^{3}$ Utku Erdem Soyaltın, ${ }^{1}$ Harun Akar ${ }^{1}$ \\ ${ }^{1}$ Department of Internal Medicine, Tepecik Training and Research Hospital, İzmir, Turkey \\ ${ }^{2}$ Department of Internal Medicine, Ceylanpinar State Hospital, Șanliurfa, Turkey \\ ${ }^{3}$ Department of Ophthalmology, Tepecik Training and Research Hospital, İzmir, Turkey
}

\begin{abstract}
Objectives: In this trial, we aimed to define arterial stiffness (AS) parameters in patients with type 2 diabetes mellitus (DM) without any known coronary heart disease and compare our results with the incidence of complications of type 2 DM like abdominal obesity, nephropathy and retinopathy in our study population.

Patients and methods: We included 110 type 2 DM patients between the ages of 30-80, without any coronary heart disease with estimated glomerular filtration rate (eGFR) value of above $30 \mathrm{~m} / \mathrm{min} / 1.73 \mathrm{~m}^{2}$ to our study. We recorded patients', body weight, body mass indexes (BMI), conicity indexes $(\mathrm{Cl})$, waist circumferences, onset of diabetes, smoking habits, fundus evaluation, hypertension and hyperlipidemia background. Moderately increased albuminuria was used as a marker to identify the diabetic nephropathy. We measured the pulse wave velocity (PWV), augmentation index (Alx), arterial blood pressure of patients by using Mobil-O-Graph ${ }^{\circledR}$ ARC solver algorithm" device.

Results: PWV values were positively associated with $\mathrm{Cl}$, onset of type $2 \mathrm{DM}$, and systolic blood pressure. PWV values were negatively associated with eGFR. Alx values were positively associated with BMI, systolic blood pressure and heart rate. Alx values were negatively associated with hemoglobin level. Hypertension was positively associated with PWV. Smoking habits was negatively associated with Alx. There were no statistically association among complications of diabetes such as nephropathy, retinopathy and PWV, Alx values.

Conclusion: There were associations between AS and Cl, eGFR, hemoglobin level, onset of diabetes, arterial blood pressure values of type 2 DM patients. There were no association between AS and nephropathy, retinopathy rates of type $2 \mathrm{DM}$ patients. We assume that AS is an independent novel cardiovascular risk factor for patients diagnosed with obesity, anemia, hypertension and type 2 DM.

Keywords: Arterial stiffness; diabetes mellitus; nephropathy; obesity; retinopathy.
\end{abstract}

öz

Amaç: Bu çalışmada, bilinen koroner arter hastalık öyküsü olmayan tip 2 diyabetes mellitus (DM) tanılı hastalarda arteriyel sertlik parametrelerinin belirlenmesi ve arteriyel sertliğin abdominal obezite, nöropati, nefropati gibi diyabetes mellitus komplikasyonları ile karşılaştırılmasını amaçladık.

Hastalar ve yöntemler: Çalışmamıza; tip 2 DM tanılı, koroner arter hastalık öyküsü olmayan, tahmini glomerüler filtrasyon hızı (eGFR): $30 \mathrm{~mL} / \mathrm{min} / 1.73 \mathrm{~m}^{2 \prime}$ nin üzerinde olan, 30-80 yaş arasında bulunan 110 hasta dahil edildi. Hastaların vücut ağırlığı, vücut kütle indeksi (VKI), konisite indeksi (Ki), bel çevresi, laboratuvar tetkikleri, diyabet süresi, sigara kullanımı, göz dibi bakısı, hipertansiyon ve hiperlipidemi öyküsü kaydedildi. Diyabetik nefropatiyi tanımlamak için belirteç olarak orta derecede artmış albuminüri kullanıldı. Hastaların nabız dalga hızı (NDH), augmentasyon indeksi (Alx) ve arteriyel kan basıncı, "Mobil-O-Graph ${ }^{\circledR}$ ARC solver algorithm" cihazı ile tek koldan ölçüldü.

Bulgular: NDH değerleri ile $\mathrm{Cl}$, tip $2 \mathrm{DM}$ süresi ve arteriyel kan basıncı arasında pozitif yönlü ilişki saptandı. NDH ve eGFR değeri arasında ise negatif yönlü bir ilişki vardı. Alx değerleri ile VKi , sistolik kan basıncı ve kalp hızı arasında pozitif yönlü llişki vardı. Alx değerleri ile hemoglobin düzeyi arasında ise negatif yönlü bir iliş̧i vardı. Hipertansiyon ile NDH pozitif ilişkili idi. Sigara içimi ile Alx negatif yönlü ilişkili idi. Hastaların diyabet komplikasyonları (nefropati ve retinopati) ile NDH ve Alx arasında istatistiksel olarak anlamlı bir fark saptanmadı.

Sonuç: Tip 2 DM'li hastaların KI, eGFR, hemoglobin düzeyleri , tip 2 DM süresi ve arteriyel kan basıncl; arteriyel sertlik ile ilişkili idi. Nefropati ve retinopati ile arteriyel sertlik arasında ilişki saptanmadı. Arteriyel sertliğin obezite, anemi, esansiyel hipertansiyon ve tip 2 DM tanılı hastalarda kardiyovasküler olaylar için bağımsız bir risk faktörü olduğunu düşünüyoruz.

Anahtar sözcükler: Arteriyel sertlik; diyabetes mellitus; nefropati; obezite; retinopati.

Received: February 25, 2015 Accepted: June 10, 2015

Correspondence: Bilgin Demir, MD. Tepecik Eğitim ve Araştırma Hastanesi Iç̧ Hastalıkları Kliniği, 35120 Yenişehir, Konak, İzmir, Turkey.

Tel: +90 544 - 8844662 e-mail: bilgin287@hotmail.com 
Diabetes mellitus (DM) is a chronic metabolic disorder which requires continuous medical care. Today all the world is facing a kind of type $2 \mathrm{DM}$ pandemic. ${ }^{[1,2]}$ According to the results of Turkey Diabetes Epidemiology Survey II (TURDEP), the prevalence of diabetes among Turkish adults has reached $13.7 \% .^{[3,4]}$ Type $2 \mathrm{DM}$ is leading cause of mortality and morbidity due to both prevalence and acute and chronic complications. ${ }^{[5]}$ The most significant causes of mortality and morbidity are cardiovascular diseases (CVD). The vascular complications can be in forms of micro- or macroangiopathy. Retinopathy, nephropathy and neuropathy are the most crucial microvascular complications. Together with hyperglycemia, hypertension (HT), smoking, dyslipidemia and obesity may also lead to microangiopathy. ${ }^{[6,7]}$

Especially in western countries, nephropathy is the main reason for end stage renal failure. It follows a path which starts with microalbuminuria and goes with constant proteinuria and deteriorating azotemia. ${ }^{[8]}$ Diabetic retinopathy is divided into two groups as nonproliferative and proliferative diabetic retinopathy. Diabetic retinopathy is the most significant cause of blindness in the world. ${ }^{[9]}$ Diagnosing the arterial stiffness parameters are one of the most effective methods in determining the elastic features of arteries. Pulse wave velocity (PWV) and augmentation index (Alx) are indexes of arterial stiffness. ${ }^{[10,11]}$

Diabetic patients stand for the independent risk group for CVD. In diabetic patients, thickening occurs in intima and media layers and atherosclerotic process speeds up owing to vascular stress and endothelial damage. Our aim is to define the relationship between obesity and microvascular complications with PWV and Alx, and to evaluate the usefulness of this test in predicting prognosis of the patients.

\section{PATIENTS AND METHODS}

This study was conducted prospectively on 128 patients with type $2 \mathrm{DM}$ who applied to Internal Medicine Outpatient Clinic between January 2014 and June 2014. The study was presented to local ethics committee of clinical research and has received approval with decision number 5 in the ethical committee meeting number 8 in $27^{\text {th }}$ August 2014. A voluntary participant form was obtained by all participants. Patients with coronary artery disease, peripheric artery disease and malignancy background and have a glomerular filtration rate under $30 \mathrm{~mL} / \mathrm{min} / 1.73 \mathrm{~m}^{2}$ were not taken into the study.

In physical examination of patients their body weight, height and waist circumferences were measured. Age, gender, smoking habits, DM duration (year), HT and hyperlipidemia (HL) backgrounds, drug history were evaluated and recorded. Body mass index (BMI) was calculated using; weigh $(\mathrm{kg}) /$ height $^{2}\left(\mathrm{~m}^{2}\right)$ formula. The conicity index $(\mathrm{CI})$ was calculated with; waist circumference $(\mathrm{WC})(\mathrm{m}) /\left(0.109^{*}\right.$ body weight $(\mathrm{kg}) /$ height $(\mathrm{m}) 1 / 2$ ) formula.

\section{Baseline clinical and laboratory methods}

Fundus examination results that were done in last three months were recorded to define retinopathy as a complication of type $2 \mathrm{DM}$. Fundus examination process: sicloplegyne 1\% eye drop was dripped and was looked by Topcon SL-3E biomicroscope (111 Bauer Drive Oakland, NJ, USA) and 90 dioptry lens after 30 minutes. Results were grouped as: Non-proliferative diabetic retinopathy (NPDR), proliferative diabetic retinopathy (PDR), blind and normal.

Fasting plasma glucose, creatinine, total chloesterol, LDL cholesterol, HDL cholesterol, uric acid, microalbumin in spot urine $(\mathrm{mg} / \mathrm{dL})$, creatinine in spot urine $(\mathrm{mg} / \mathrm{dL})$ levels of patients were measured by Olympus AO5800 autoanalyzer (Olympus America Inc., Two Corporate Center Drive, Melville, NY, USA) with enzymatic method.

Hemoglobin values were measured by Beckmen Coulter ${ }^{\circledR}$ LH 780 hematology analyzer (Beckman Coulter, Inc. Brea, CA, USA) with empedance method. Hemoglobin A1c (HbA1c 4-6\%), was measured by Premier Hb9210 HbA1c analyzer Trinity Biotech Plc, IDA Business Park, Bray, Co Wicklow, Ireland. with Boronat affinity high performance liquid chromotography (HPLC) method.

Measured microalbumin in spot urine $(\mathrm{mg} / \mathrm{dL})$, creatinine in spot urine $(\mathrm{mg} / \mathrm{dL})$ levels of patients were proportionated with each other and the level of nephropathy was classified. Nephropathy classification was arranged according to proportions as normoalbuminuria $(<0.02 \mathrm{mg} / \mathrm{mg}) \quad$ "moderately increased albuminuria (0.02-0.2 $\mathrm{mg} / \mathrm{mg}) "$ severely 
increased albuminuria ( $>0,2 \mathrm{mg} / \mathrm{mg})$. Estimated glomerular filtration rate was calculated, using modification of diet in renal disease (MDRD) formula.

Patients were divided into groups in respect to HT, HL and DM treatment. The ones who are treated for hypertension and hyperlipidemia are marked as "positive" and the ones who aren't treated for these disease are marked as "negative". Four categorizations were used for type $2 \mathrm{DM}$ treatment. These are:

1. Dieting + exercising (Diet)

2. Dieting + exercising + oral anti-diabetic agent (Diet + OAD)

3. Dieting + exercising + oral anti-diabetic agent + basal insulin (Diet + OAD + Basal)

4. Dieting + exercising + intensive insulin using (Diet + intensive)

\section{Arterial stiffness measurement}

A single cuffed arteriograph device (I.E.M. $\mathrm{GmbH}$ brand Mobil-O-Graph PWA, a model pulse wave analysis device) was used for the arterial stiffness measurements, which is using a validated oscillometric technique. ${ }^{[12,13]}$ The participants included in the study were made to rest for $10 \mathrm{~min}$ before measurement, and were required not to smoke or drink any caffeinated beverages in the
30 min leading up to measurement. Prior to measurement, the date of birth, height, weight, and smoking status of each patient were entered into the software program of the device, and the cuff was attached to side of the upper arm on the brachial artery trace. The cuff was held in line with the heart, and the device took two measurements automatically at 30-s intervals. ${ }^{[14-16]}$

PWV, Alx, systolic blood pressure (SBP), diastolic blood pressure (DBP), mean arterial pressure (MAP), heart rate of patients were recorded by this machine.

\section{Statistical analysis}

PASW version 18.0 for Windows software program (SPSS, Inc., Chicago, IL, USA) was used for statistical analysis. Defining statistics, numbers and percents for categorical variations, average for numerical variations, standard deviation, median were presented as minimum and maximum. In multiple independent group proportionating for numeric variations; if normal distribution assumption is provided, ANOVA test, if not, Kruskal Wallis test; in dualgroup proportionations, if normal distribution assumption is not provided Mann-Whitney $U$ test; if it is provided $\mathrm{T}$ test were used. For categorical variations chi-square test was used. For correlations in which normal dispersion is provided between numeric data, Pearson; if it

Table 1. Demographic and clinical characteristics of the study groups $(n=110)$

\begin{tabular}{|c|c|c|c|}
\hline & Mean \pm SD & Minimum-maximum & Median \\
\hline Age (years) & $55.82 \pm 9.33$ & $32-78$ & 56 \\
\hline Height (cm) & $164.63 \pm 8.90$ & $146-192$ & 162.5 \\
\hline Body weight $(\mathrm{kg})$ & $83.69 \pm 13.87$ & 46-113 & 82 \\
\hline Body mass index $\left(\mathrm{kg} / \mathrm{m}^{2}\right)$ & $31.33 \pm 5.87$ & $18-46.6$ & 30.45 \\
\hline Waist circumference $(\mathrm{cm})$ & $103.49 \pm 11.43$ & 61-133 & 104 \\
\hline Conicity index & $1.34 \pm 0.09$ & $1.05-1.59$ & 1.34 \\
\hline Type 2 diabetes mellitus duration (year) & $6.16 \pm 5.43$ & $0.5-23$ & 5 \\
\hline Creatinine (mg/dL) & $0.95 \pm 0.18$ & $0.6-1.4$ & 0.95 \\
\hline Low-density lipoprotein (mg/dL) & $134.12 \pm 37.00$ & 49-354 & 132 \\
\hline High-density lipoprotein (mg/dL) & $47.24 \pm 9.05$ & $28-77$ & 46 \\
\hline Hemoglobin (gr/dL) & $13.35 \pm 1.47$ & 9-18.5 & 13.3 \\
\hline Uric acid (mg/dL) & $5.30 \pm 1.48$ & $1.6-9.5$ & 4.95 \\
\hline Hemoglobin A1c (\%) & $7.93 \pm 2.26$ & 4.9-14.8 & 7.3 \\
\hline Estimated glomerular filtration rate $\left(\mathrm{mL} / \mathrm{min} / 1.73 \mathrm{~m}^{2}\right)$ & $76.65 \pm 15.00$ & 44.6-111 & 78.54 \\
\hline Microalbumin spot urine/creatinine (mg/dL) & $0.06 \pm 0.15$ & $0.001-0.9$ & 0.01 \\
\hline Fasting plasma glucose (mg/dL) & $167.51 \pm 72.59$ & 83-423 & 144 \\
\hline Pulse wave velocity $(\mathrm{m} / \mathrm{s})$ & $8.41 \pm 1.39$ & $5.3-12.5$ & 8.25 \\
\hline Augmentation index (75\%) & $29.69 \pm 12.18$ & $2-53$ & 31 \\
\hline Systolic blood pressure (mmHg) & $135.35 \pm 16.74$ & $96-177$ & 134.5 \\
\hline Diastolic blood pressure (mmHg) & $84.13 \pm 10.49$ & $63-126$ & 84 \\
\hline Mean arterial pressure (mmHg) & $107.73 \pm 11.69$ & $81-145$ & 106 \\
\hline Heart rate & $85.75 \pm 12.04$ & $52-115$ & 84 \\
\hline
\end{tabular}

SD: Standard deviation 
is not provided Spearman's rho test was used. The value for being statistically meaningful level $p$ was accepted to be $<0.05$.

\section{RESULTS}

Since 12 of these patients' estimated glomerular filtration rate (eGFR) were found to be less than $30 \mathrm{~mL} / \mathrm{min} / 1.73 \mathrm{~m}^{2}$; two of the patients didn't apply to us after blood examination, four patients were diagnosed to have coronary artery disease backgrounds after the detailed examination of the anamnesis, these patients weren't taken into study. The other 110 type $2 \mathrm{DM}$ patients (48 males, 62 females; avarage age 55.82 \pm 9.33 years; range 30 to 80 years) were enrolled into the study.

The average BMI of patients was 31.33 $(18-46.6) \mathrm{kg} / \mathrm{m}^{2}$. Average CI was calculated as
1.34, PWV; as $8.41 \mathrm{~m} / \mathrm{s}$, AIx as 29.69\%. The demographic and clinical features of the patients are shown in (Table 1).

The demographic features, diabetes durations, blood pressures and laboratory results of patients were compared with PWV and Alx data. There was a statistical positive relation of PWV with $\mathrm{CI}$, type $2 \mathrm{DM}$ duration, HDL, SBP, and MAP values; where as a statistical negative relation with eGFR value (in order $p=0.001$, $p=0.002, p=0.001, p<0.001, p=0.001, p<0.001$ ) (Figure 1). There was a statistical positive relation between Alx and BMI, SBP and heart rate (HR) values; and a statistical negative relation with hemoglobin $(\mathrm{Hb})$ value (in order $\mathrm{p}=0.025$, $\mathrm{p}=0.019, \mathrm{p}<0.001, \mathrm{p}=0.024$ ) (Table 2).

Fifty-seven patients (51.8\%) were diagnosed with HT, 51 patients (46.4\%) were diagnosed
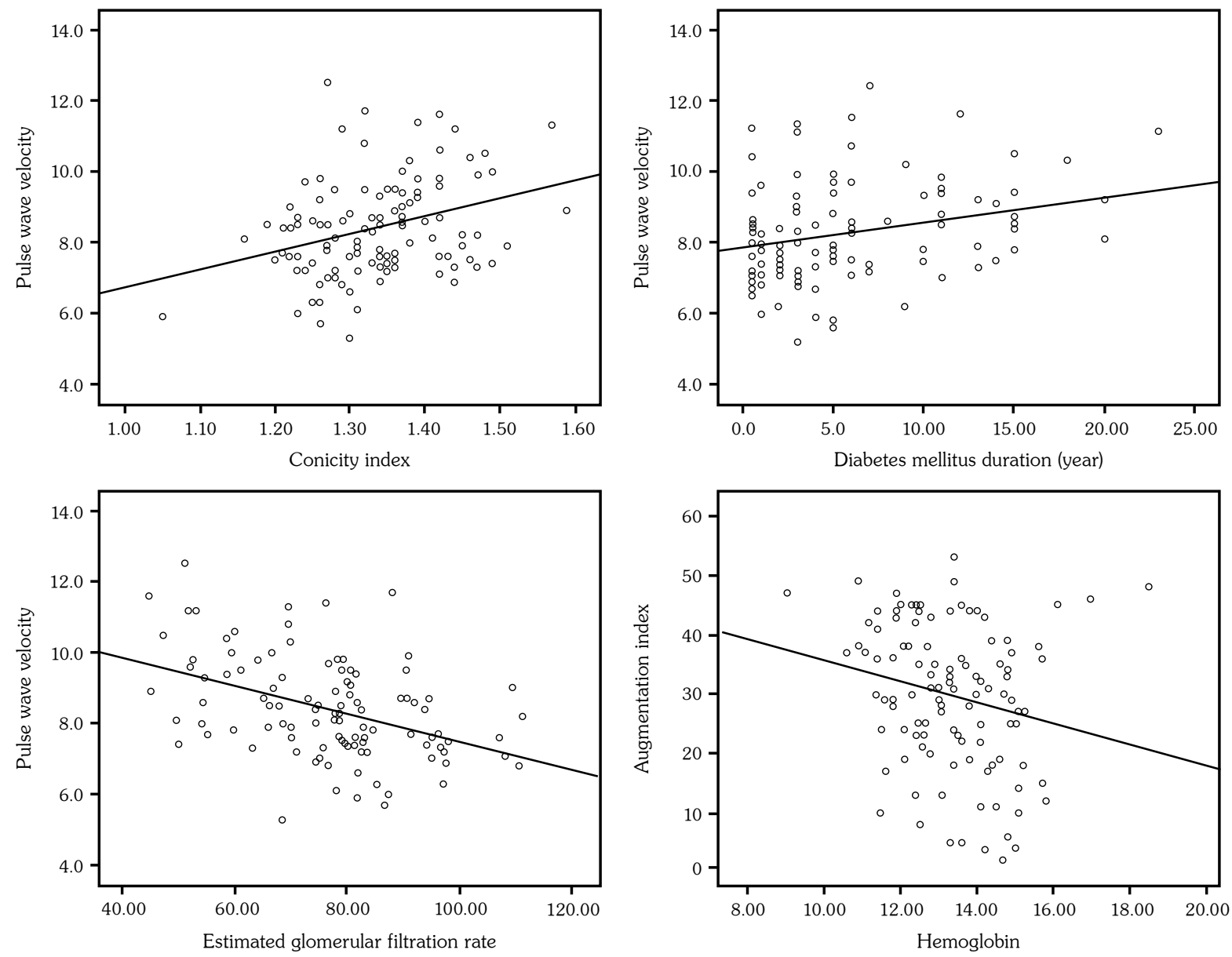

Figure 1. Statistical comparison of pulse wave velocity and conicity index, type 2 diabetes mellitus duration, estimated glomerular filtration rate, augmentation index and hemoglobin. 
Table 2. The results of the correlation analysis showing the associations among arterial stiffness and all clinical and laboratory parameters

\begin{tabular}{|c|c|c|c|c|}
\hline & \multicolumn{2}{|c|}{ Pulse wave velocity } & \multicolumn{2}{|c|}{ Augmentation index } \\
\hline & Coefficient(r) & $p$ & Coefficient(r) & $p$ \\
\hline Body mass index & -0.022 & 0.816 & 0.214 & 0.025 \\
\hline Waist circumference & 0.137 & 0.154 & 0.147 & 0.125 \\
\hline Conicity index & 0.307 & 0.001 & 0.096 & 0.317 \\
\hline Diabetes mellitus duration (year) & 0.292 & 0.002 & 0.088 & 0.359 \\
\hline Total cholesterol & 0.035 & 0.713 & 0.067 & 0.484 \\
\hline Low-density lipoprotein & -0.011 & 0.910 & 0.005 & 0.962 \\
\hline High-density lipoprotein & 0.308 & 0.001 & 0.103 & 0.286 \\
\hline Hemoglobin & -0.138 & 0.151 & -0.214 & 0.024 \\
\hline Uric acid & 0.150 & 0.118 & 0.122 & 0.204 \\
\hline $\mathrm{HbA1c}$ & -0.151 & 0.114 & -0.073 & 0.449 \\
\hline Estimated glomerular filtration rate & -0.418 & $<0.001$ & 0.006 & 0.953 \\
\hline Fasting plasma glucose & -0.175 & 0.067 & -0.120 & 0.213 \\
\hline Systolic blood pressure & 0.467 & $<0.001$ & 0.224 & 0.019 \\
\hline Diastolic blood pressure & 0.044 & 0.651 & 0.023 & 0.815 \\
\hline Mean arterial pressure & 0.318 & 0.001 & 0.119 & 0.216 \\
\hline Hart rate & -0.105 & 0.273 & 0.328 & $<0.001$ \\
\hline
\end{tabular}

with hyperlipidemia; 53 patients (48.2\%) weren't diagnosed with HT, 59 patients (53.6\%) weren't diagnosed with hyperlipidemia. $31.8 \%(n=35)$ patients were cigarette smokers; $68.2 \%(n=75)$ weren't smokers. In terms of statistical PWV value the HT patients were higher than the ones who weren't hypertensive. In terms of statistical Alx averages smokers were lower than non-smokers (in order $\mathrm{p}<0.001 ; \mathrm{p}=0.018$ ) (Figure 2, 3). Some parameters which are likely to effect the reason for low Alx in smoking patients were taken into consideration. The relation between smoking and $\mathrm{WC}, \mathrm{CI}, \mathrm{BMI}$ was examined. Despite not being statically illogical, non-smokers were defined to have higher BMI, $\mathrm{CI}$ and WC (Table 3).

Twenty-nine patients (26.4\%) were diagnosed with diabetic retinopathy; 81 patients (73.6\%) weren't diagnosed diabetic retinopathy. Ten patients $(9.1 \%)$ with diabetic retinopathy were

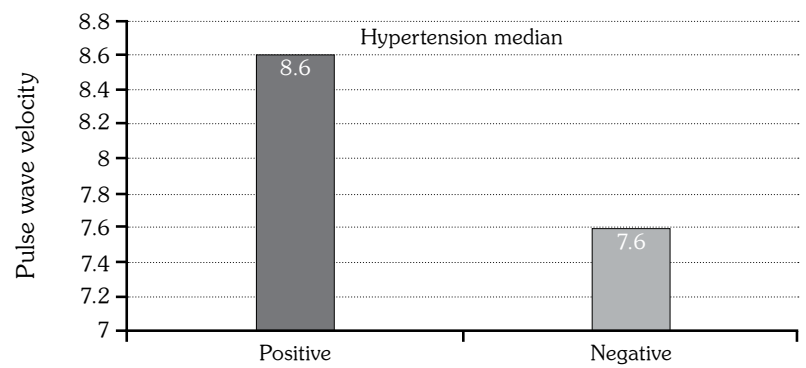

Figure 2. Comparison of pulse wave velocity values between hypertensive and non hypertensive group. diagnosed with PDR, 19 (17.3\%) of them were diagnosed with NPDR. Thirty (27.3\%) of the patients were diagnosed with nephropathy while $80(72.7 \%)$ of them weren't. Twentyone (19.1\%) of the patients with nephropathy were in microalbuminuric phase, nine (8.2\%) of them were in macroalbuminuric phase. No statistical distinction of diabetes complications (nephropathy and retinopathy) was seen with PWV and AI (Table 4).

Fifty-five (50\%) of the patients were using an antihypertensive medication, 32 (29.1\%) of them were using an antihyperlipidemic medication; while 55 (50\%) of them were not using any antihypertensive medication and 78 (70.9\%) of them weren't using any antihyperlipidemic medication. The patients being treated for type 2 DM were defined as: 2 (18\%) Dieting,

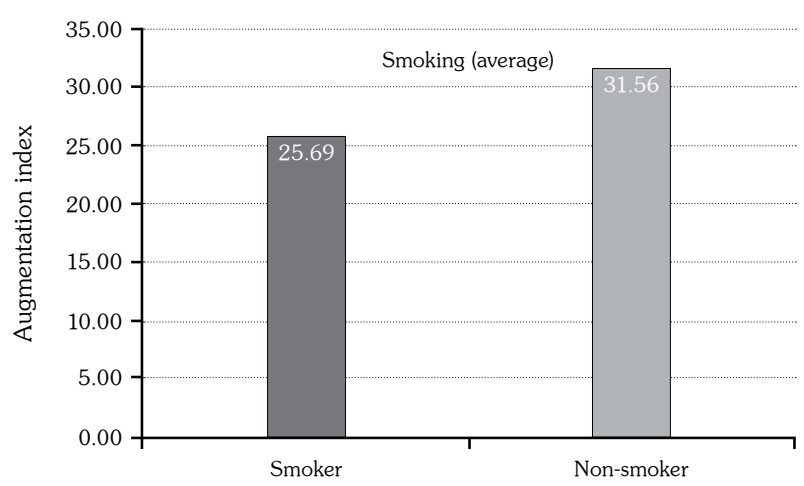

Figure 3. Comparison of augmentation index values between smokers and non smokers. 
Table 3. The relationship between smoking and conicity index, body mass index and waist circumference

\begin{tabular}{|c|c|c|c|c|c|c|c|}
\hline & \multicolumn{6}{|c|}{ Smoking habit } & \multirow[b]{3}{*}{$p$} \\
\hline & \multicolumn{3}{|c|}{ Smoker } & \multicolumn{3}{|c|}{ Non-smoker } & \\
\hline & Mean \pm SD & Median & Minimum-maximum & Mean \pm SD & Median & Minimum-maximum & \\
\hline Body mass index & & 28.7 & $18.9-46.6$ & & 31.2 & $18-45.8$ & 0.211 \\
\hline Conicity index & $1.33 \pm 0.07$ & & & $1.34 \pm 0.10$ & & & 0.436 \\
\hline Waist circumference & $101.94 \pm 11.72$ & & & $104.21 \pm 11.29$ & & & 0.334 \\
\hline
\end{tabular}

Table 4. The comparison of type 2 diabetes mellitus complications and arterial stiffness parameters

\begin{tabular}{|c|c|c|c|c|c|}
\hline & \multicolumn{2}{|c|}{ Pulse wave velocity } & \multirow[b]{2}{*}{$p$} & \multirow{2}{*}{$\frac{\text { Augmentation index }}{\text { Mean } \pm S D}$} & \multirow[b]{2}{*}{$p$} \\
\hline & Median & Minimum-maximum & & & \\
\hline \multicolumn{6}{|l|}{ Retinopathy } \\
\hline Negative & 8.1 & $5.3-11.6$ & & $29.67 \pm 12.28$ & \\
\hline Proliferative diabetic retinopati & 8.35 & 7.6-11.7 & 0.362 & $31.50 \pm 14.12$ & 0.857 \\
\hline Non proliferative diabetic retinopathy & 8.6 & $5.9-12.5$ & & $28.84 \pm 11.26$ & \\
\hline \multicolumn{6}{|l|}{ Albuminuria } \\
\hline Normoalbuminuria & 8.25 & $5.3-12.5$ & & $29.93 \pm 11.05$ & \\
\hline Microalbuminuria & 7.9 & $6-11.6$ & 0.124 & $27.48 \pm 15.54$ & 0.526 \\
\hline Macroalbuminuria & 9.3 & $7.6-10.6$ & & $32.78 \pm 13.74$ & \\
\hline
\end{tabular}

$71(64.5 \%)$ Dieting + OAD, nine (8.2\%) Dieting + OAD + Basal, 28 (25.5\%) Dieting + intensive. Patients having antihypertensive medications had a higher PWV value than the ones who aren't $(p<0.001)$. Arterial stiffness parameters were not statistically significant in the patients being treated for hyperlipidemia and type $2 \mathrm{DM}$ (Figure 4, 5).

\section{DISCUSSION}

Arterial stiffness leads to prediction of CVD in general population, hypertensive patients and diabetics. The golden standard in measurement of arterial stiffness is aortic PWV measurement. PWV measurement in office conditions contributes to prediction of cardiovascular complications beyond other risk factors. Each

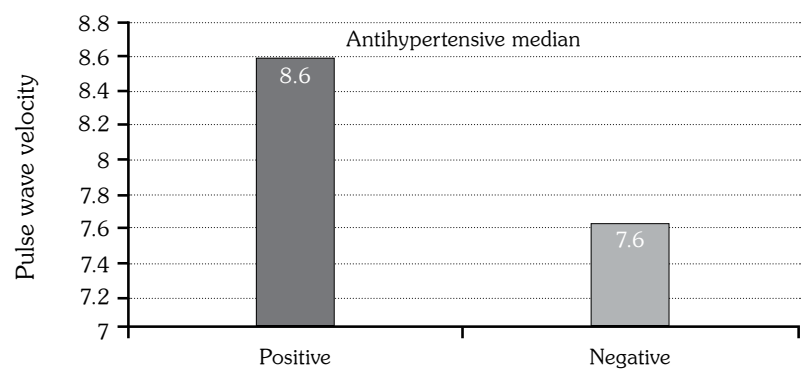

Figure 4. Comparison of pulse wave velocity values between treated hypertensive group and non-treated hypertensive group. one standard deviation rise in PWV value leads to $16-20 \%$ rise in the risk of CVD. ${ }^{[17]}$

In this study a statistically positive relation was diagnosed between PWV and type 2 DM duration, HDL, SBP, MAP values. In a study by Theilade et al. ${ }^{[18]}$ in type $1 \mathrm{DM}$ patients, a positive correlation $(\mathrm{r}=0.54)$ between PWV and diabetes duration was seen. In a study by Cruickshank et al. ${ }^{[19]}$ it was seen that as glucose tolerance fell, PWV values rose.

Conicity index and BMI, which are antropometric measurements and used for obesity, were also looked in this study. A statistically meaningful correlation was seen between PWV and CI. The patients who have renal failure criteria were examined in the study of Evans et al. ${ }^{[20]}$ and it was seen that there was a statistically negative association between BMI

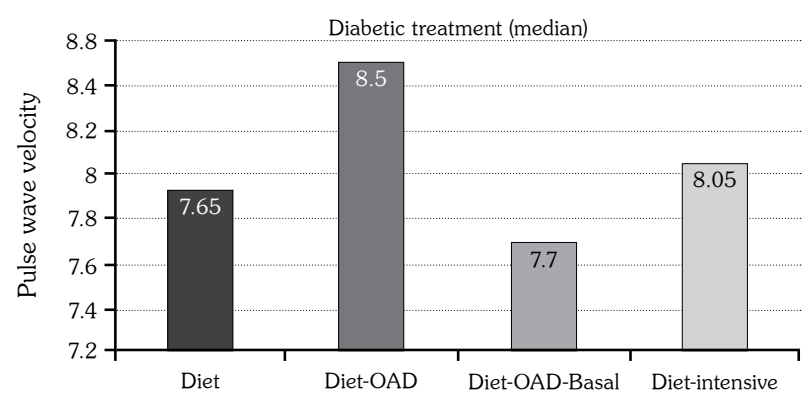

Figure 5. Comparison of pulse wave velocity values between anti-diabetic treatment groups. 
and PWV. In the same study it was found that as the $\mathrm{CI}$ value of the patients increased their PWV value increased $(p<0.001)$.

There was no statistically significant correlation between PWV and albuminuria level which shows nephropathy stage. In the study of Theilade et al. ${ }^{[18]}$ a positive correlation between PWV and excretion ratio was found. Also it was seen in the same study that in normoalbuminuric type 1 DM patients, PWV was relatively high in comparison to control group. This finding supports the idea of the relation between of DM existence and arterial stiffness in early stages. In our study a statistically meaningful negative relation was seen between PWV and eGFR. Same findings were seen in the study of Theilade et al. ${ }^{[18]}$ and Smith et al. ${ }^{[21]}$ It was also shown that as a falling occurs in creatinine clearance in the patients who don't have DM and end stages renal disease, PWV rose. ${ }^{[22,23]}$ It can be thought that early modifications in renal functions not only trigger stiffness in small arteries but also in big arteries. With the studies conducted, the essential factors that determine PWV values are: age, gender, PWV, albumin/creatinine proportion, diabetes duration, the number of antihypertensive medicine, ACEI/ARB usage, creatinine clearance, fasting plasma glucose. ${ }^{[21,22]}$

In our study the ones with HT story were found to have statistically higher PWV values than the ones who don't have a HT story. In the study of Cruickshank et al. ${ }^{[19]}$ the findings are similar to ours. After the long-term follow-up of this study, in died patients PWV was about $2.6 \mathrm{~m} / \mathrm{sec}$ higher and SBP was $10 \mathrm{mmHg}$ higher in comparison to living patients. In terms of mortality PWV was diagnosed to be relatively predictive.

In different studies, some pharmacologic agents were studied in terms of arterial stiffness. In the ones who use more antihypertensive, ACE/ $\mathrm{ARB}$ and take antihypertensive treatment like in our study, PWV was seen to be higher. ${ }^{[18,21]}$ These findings points to vascular disease which has been going on longer. CAFE study showed that the effect of antihypertensive treatment on central blood pressure, in comparison with effect on lowering the blood pressure, is a better indicator in reflecting the cardiovascular conditions. ${ }^{[24]}$

There are contradictory information between diabetes treatment and PWV. In our study, a statistically meaningful distinction wasn't seen in terms of PWV and Alx values between, the patient groups who were divided into groups according to their diet, exercise, oral antidiabetic and insulin treatments. In a study by Kim et al. ${ }^{[25]}$ it was shown that rosiglitazone decreases PWV by increasing the insulin sensitivity. In another study it was shown that insulin treatment increases PWV ${ }^{[26]}$ possibly due to increased anabolic effects of insulin. This subject hasn't been fully clarified yet and so bigger studies are needed.

In our study, a reverse relation between smoking and Alx was seen. So, when the other parameters that may effect arterial stiffness were examined it was seen that BMI and $\mathrm{CI}$ in nonsmokers were higher. It can be thought that BMI and CI may be as effective as cigarette in effecting arterial stiffness.

In comparison with other studies ${ }^{[18,27]}$ no relation between retinopathy and arterial stiffness was seen. This may be due to the small number of our patient group.

Some studies have been carried out to evaluate the relation between PWV and inflammation paremeters. The inflammation parameters which show subclinic organ damage $(\mathrm{C}$ reactive protein, interleukin-6, tumor necrosis factor alpha) are connected with PWV. ${ }^{[28-31]}$ In our study uric acid values were examined as the indirect parameter of inflammation. No statistically meaningful relation between PWV values and uric acid level was seen.

\section{Conclusion}

The CI, eGFR hemoglobin, diabetes duration and arterial blood pressure of patients with DM were found to be related with arterial stiffness. No relation between nephropathy and retinopathy with arterial stiffness were seen. Diabetes mellitus is equal to coronary artery disease. Arterial stiffness is used as a predicting parameter for coronary artery disease. We are of the opinion that arterial stiffness is a novel risk factor of CVD for obesity, anemia, essential hypertension and in type $2 \mathrm{DM}$ patient group.

\section{Declaration of conflicting interests}

The authors declared no conflicts of interest with respect to the authorship and/or publication of this article. 


\section{Funding}

The authors received no financial support for the research and/or authorship of this article.

\section{REFERENCES}

1. King H, Rewers M. Global estimates for prevalence of diabetes mellitus and impaired glucose tolerance in adults. WHO Ad Hoc Diabetes Reporting Group. Diabetes Care 1993;16:157-77.

2. King H, Aubert RE, Herman WH. Global burden of diabetes, 1995-2025: prevalence, numerical estimates, and projections. Diabetes Care 1998;21:1414-31.

3. Satman İ, Yllmaz T. Dünyada ve Türkiye'de obezite epidemiyolojisi. Aktüel Tip Dergisi 2001;6:9-12.

4. Satman İ ve TURDEP-II Çalışma Grubu. 32. TEMH Kongresi 13-17 Ekim 2010, Antalya.

5. Laakso M. Tip 2 diyabetin epidemiyolojisi ve tanıs1. In: Goldstein BJ, Müler-Wieland D, editors. Textbook of Type 2 Diabetes. New York: Martin Dunitz Group 2003. Çeviri Ed: Akman AC. 1. Baskı. İstanbul: AND Yayıncilik; 2004. s. 1-12.

6. Yenigün M. Her yönüyle diabetes mellitus. 2. Baskı. İstanbul: Nobel Tip Kitabevi; 2001.

7. Koloğlu S. Diyabetes mellitus. In: Koloğlu S, editör. Endokrinoloji Temel ve Klinik. 1. Baskı. Ankara: Medical Network \& Nobel; 1996. s. 368-85.

8. İliçin G, Biberoğlu K, Süleymanlar G, Ünal S. İç hastalıkları. Ankara: Güneş Kitabevi; 2003. s. 51.

9. Mogensen CE. Microalbuminuria, blood pressure and development on ideas. Diabetologica 1999;41:736-41.

10. Laurent S, Cockcroft J, Van Bortel L, Boutouyrie P, Giannattasio C, Hayoz D, et al. Expert consensus document on arterial stiffness: methodological issues and clinical applications. Eur Heart $\mathrm{J}$ 2006;27:2588-605.

11. Laurent S, Boutouyrie P. Recent advances in arterial stiffness and wave reflection in human hypertension. Hypertension 2007;49:1202-6.

12. Akdam H, Öğünç H, Alp A, Özbek Ö, Ömürlü İK, Yeniçerioğlu Y, et al. Assessment of volume status and arterial stiffness in chronic kidney disease. Ren Fail 2014;36:28-34.

13. Jatoi NA, Mahmud A, Bennett K, Feely J. Assessment of arterial stiffness in hypertension: comparison of oscillometric (Arteriograph), piezoelectronic (Complior) and tonometric (SphygmoCor) techniques. J Hypertens 2009;27:2186-91.

14. Horváth IG, Németh A, Lenkey Z, Alessandri N, Tufano $\mathrm{F}$, Kis $\mathrm{P}$, et al. Invasive validation of a new oscillometric device (Arteriograph) for measuring augmentation index, central blood pressure and aortic pulse wave velocity. J Hypertens 2010;28:2068-75.

15. Baulmann J, Schillings U, Rickert S, Uen S, Düsing $\mathrm{R}$, Illyes $\mathrm{M}$, et al. A new oscillometric method for assessment of arterial stiffness: comparison with tonometric and piezo-electronic methods. J Hypertens
2008;26:523-8.

16. McEniery CM, Yasmin, McDonnell B, Munnery M, Wallace SM, Rowe CV, et al. Central pressure: variability and impact of cardiovascular risk factors: the Anglo-Cardiff Collaborative Trial II. Hypertension 2008;51:1476-82.

17. Willum-Hansen T, Staessen JA, Torp-Pedersen C, Rasmussen S, Thijs L, Ibsen $\mathrm{H}$, et al. Prognostic value of aortic pulse wave velocity as index of arterial stiffness in the general population. Circulation 2006;113:664-70.

18. Theilade S, Lajer M, Persson F, Joergensen C, Rossing $P$. Arterial stiffness is associated with cardiovascular, renal, retinal, and autonomic disease in type 1 diabetes. Diabetes Care 2013;36:715-21.

19. Cruickshank K, Riste L, Anderson SG, Wright JS, Dunn G, Gosling RG. Aortic pulse-wave velocity and its relationship to mortality in diabetes and glucose intolerance: an integrated index of vascular function? Circulation 2002;106:2085-90..

20. Evans PD, McIntyre NJ, Fluck RJ, McIntyre CW, Taal MW. Anthropomorphic measurements that include central fat distribution are more closely related with key risk factors than BMI in CKD stage 3. PLoS One 2012;7:34699.

21. Smith A, Karalliedde J, De Angelis L, Goldsmith D, Viberti G. Aortic pulse wave velocity and albuminuria in patients with type 2 diabetes. J Am Soc Nephrol 2005;16:1069-75.

22. Mourad JJ, Pannier B, Blacher J, Rudnichi A, Benetos A, London GM, et al. Creatinine clearance, pulse wave velocity, carotid compliance and essential hypertension. Kidney Int 2001;59:1834-41.

23. Aoun S, Blacher J, Safar ME, Mourad JJ. Diabetes mellitus and renal failure: effects on large artery stiffness. J Hum Hypertens 2001;15:693-700.

24. Williams B, Lacy PS, Thom SM, Cruickshank K, Stanton A, Collier D, et al. Differential impact of blood pressure-lowering drugs on central aortic pressure and clinical outcomes: principal results of the Conduit Artery Function Evaluation (CAFE) study. Circulation 2006;113:1213-25.

25. Kim SG, Ryu OH, Kim HY, Lee KW, Seo JA, $\mathrm{Kim} \mathrm{NH}$, et al. Effect of rosiglitazone on plasma adiponectin levels and arterial stiffness in subjects with prediabetes or non-diabetic metabolic syndrome. Eur J Endocrinol 2006;154:433-40.

26. Smith A, Karalliedde J, De Angelis L, Goldsmith D, Viberti G. Aortic pulse wave velocity and albuminuria in patients with type 2 diabetes. J Am Soc Nephrol 2005;16:1069-75.

27. Yun YW, Shin MH, Lee YH, Rhee JA, Choi JS. Arterial stiffness is associated with diabetic retinopathy in Korean type 2 diabetic patients. J Prev Med Public Health 2011;44:260-6.

28. Dahlén EM, Tengblad A, Länne T, Clinchy B, Ernerudh J, Nystrom FH, et al. Abdominal obesity and low-grade systemic inflammation as markers of subclinical organ damage in type 2 diabetes. Diabetes 
Metab 2014:40:76-81

29. Teoh W, Price JF, Williamson RM, Payne RA, Van Look LA, Reynolds RM, et al. Metabolic parameters associated with arterial stiffness in older adults with Type 2 diabetes: the Edinburgh Type 2 diabetes study. J Hypertens 2013;31:1010-7.

30. Nagano M, Nakamura M, Sato K, Tanaka F, Segawa $\mathrm{T}$, Hiramori K. Association between serum C-reactive protein levels and pulse wave velocity: a populationbased cross-sectional study in a general population. Atherosclerosis 2005;180:189-95.

31. Mattace-Raso FU, van der Cammen TJ, van der Meer IM, Schalekamp MA, Asmar R, Hofman A, et al. C-reactive protein and arterial stiffness in older adults: the Rotterdam Study. Atherosclerosis 2004;176:111-6. 